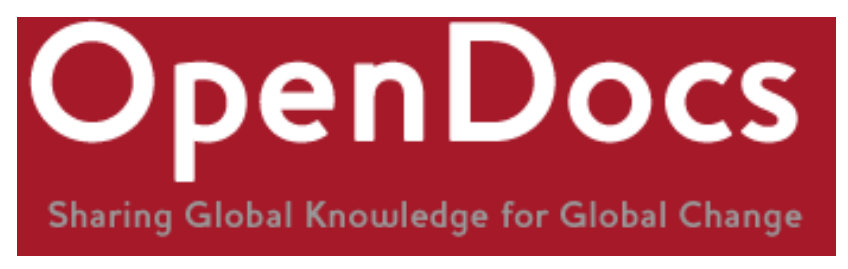

Title: Mutable meanings: gender equality in education and international rights frameworks

Citation: Unterhalter, Elaine (2012) Mutable meanings: gender equality in education and international rights frameworks. Equal Rights Review, 8. pp. 67-84. ISSN: 1757-1650.

Official URL: http://www.equalrightstrust.org/ertdocumentbank/ERR8 Elaine Unterhalter.pdf

More details/abstract: Gender equality in education has considerable prominence in a wide range of international treaties and declarations, encompassing those concerned with human rights, gender equality, the expansion of education and the reduction of poverty. Despite this, however, it has not been easy to realise gender equality in education at the national and local level in many countries. Although statistics on rising numbers of girls and boys enrolling in school and the improvements in attainment by many girls suggest large steps towards equality, these often mask persistent inequalities in which gender features prominently. This article examines why the international frameworks relating to gender equality in education are so difficult to realise. The discussion draws mainly on data collected from a three year research project in Kenya and South Africa on how international frameworks concerned with poverty, gender equality and education were negotiated in a range of local settings.

Version: Accepted version

Terms of use: This is an Accepted Manuscript of an article published by The Equal Rights Trust in Equal Rights Review available online at:

http://www.equalrightstrust.org/ertdocumentbank/ERR8 Elaine Unterhalter.pdf

This is a download from OpenDocs at the Institute of Development Studies

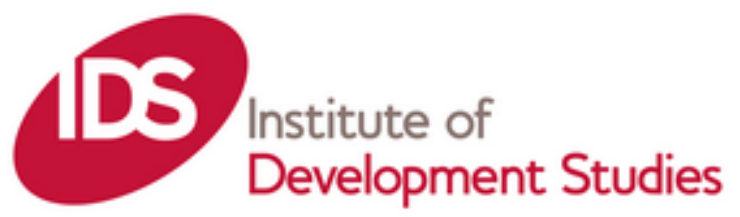




\section{Mutable Meanings: Gender Equality in Education and International Rights Frameworks}

\section{Elaine Unterhalter ${ }^{1}$}

Gender equality in education has considerable prominence in a wide range of international treaties and declarations, encompassing those concerned with human rights, gender equality, the expansion of education and the reduction of poverty. Despite this, however, it has not been easy to realise gender equality in education at the national and local level in many countries. Although statistics on rising numbers of girls and boys enrolling in school and the improvements in attainment by many girls suggest large steps towards equality, these often mask persistent inequalities in which gender features prominently. This article examines why the international frameworks relating to gender equality in education are so difficult to realise. The discussion draws mainly on data collected from a three year research project in Kenya and South Africa on how international frameworks concerned with poverty, gender equality and education were negotiated in a range of local settings. ${ }^{2}$ The first part of the article reviews different ways in which gender equality in education can be understood, and associates these with contrasting approaches within the relevant international frameworks. The second part distinguishes between: (i) those international frameworks that work with a very restricted notion of gender equality and education, and (ii) those which deploy a more expansive meaning. In the third section some of the findings from a research study in Kenya and South Africa are presented in order to demonstrate which features of the conventions and declarations are implemented in different sites, highlighting how the conceptual distinction between different meanings of gender and equality and forms of international framework have a bearing on the forms of implementation.

\section{Conceptualising Gender Equality in Education}

The very ubiquity of concern with gender equality in education masks considerable conceptual confusion with regard to what is meant by gender inequality and equality and the particular sense of education that is evoked. ${ }^{3}$ At least four different frameworks can be distinguished and a number of metaphors are useful for analysing the different relationships at play within each.

Firstly, in thinking about education as enrolling in school, attaining literacy or completing a phase of study, one can conceptualise education as "a line". This has similarities with views of poverty as a particular level of earnings or consumption. Thus one can count the numbers of women and men, girls and boys, which are above or below an education attainment or poverty line. The UNESCO Global Monitoring Report draws directly on this notion in understanding education as those who are above or below a distributional level of two or four years at school. ${ }^{4}$ These ideas 
about education and poverty work with an understanding of what I have called "gender as a noun". In this view, gender is a descriptive identification of numbers of girls and boys in or out of school, or achieving particular grades or levels of employment. Using this approach, gender equality in education can be understood as parity, that is equal numbers, and gender inequality as the number of girls as a proportion of the number of boys in any particular phase of schooling or form of attainment. What this very limited notion of equality misses out is the structural relations of power and inequality in a range of political, economic, social and cultural spheres, and the many connected sites in which equality needs to be realised. Despite this very limited meaning of "gender as a noun" (i.e. education as attainment at school, and equality as sameness or parity), this is the meaning most often deployed in some widely used international frameworks as discussed below.

A second way to think about gender is one which draws out the interconnections of relationships associated with power and meaning in different sites, both between men and women, and girls and boys. This is linked with a view of education that is wider than that limited to years of enrolment in school or attainment in particular tests. It explores how schools and processes of learning operate both to reproduce and to transform inequalities. This approach highlights the way in which (i) the curriculum is gendered, (ii) particular assumptions are made by teachers and managers about what kinds of knowledge are appropriate for girls and boys, and (iii) there are subjects defined as being either those which girls are "good" at or those which they are not. This approach notes the ways in which girls are channeled into lower status subjects and career paths. Many studies of textbooks document how they are com- plicit with the reproduction of stereotypes about women and men, while key works look at the question of learning in terms of how school relationships might be complicit with gender based violence. ${ }^{6}$ This view of gender and schooling resonates with discussions of poverty, where what is noted is not a particular level of earnings, but rather the structural relationships of subordination, exploitation and exclusion. I have referred to this as the notion of poverty as "a net". Relationships at school may also be interwoven within such a net. This is a net in which the economic relations of survival, including the sexual division of labour in the household, mean that, despite what may open up at school, it is difficult to transform gender relationships which are enmeshed with particular relations of production concerning the kinds of work that are available for women and men. In this type of analysis, gender is understood as a feature of interconnected household, community and national power relationships. I have termed this "gender as an adjective"; an attribute of the relationships of power which form structures of inequality. ${ }^{7}$ Hence gendered relationships in schools articulate with wider relationships in both meanings of the term. The boundaries and networks that discursively form the net of poverty or schooling (and speak or articulate it) are as much constituted by coercive economic and political relations as by inequality maintained over generations associated with divisions of race, ethnicity, caste or location (which are all connected). Gender equality in education is thus a process of both naming and changing the relationships of inequality, which is undertaken in the knowledge that schooling is a necessary, but not a sufficient, process to ensure that this is achieved.

A third way to think about the relationship between the concepts of gender, equality, inequality and education is associated with 
the ways in which gender is discursively formed and reformed in language and action. Discourses, evident in policy, media, and everyday talk, set limits on how it is possible to think and act with regard to gender relationships, identities and the possibilities of change. In writing about poverty, I have drawn attention to the way in which one can think about poverty as "a fuel", using two meanings of the word fuel. ${ }^{8}$ Fuel is what can propel you forward, energise, and result in an activism that can move an individual or a community out of poverty. But a fuel, such as petrol, is also a toxin. Some forms of identification evident in studies of the "voices of the poor" are associated with adaptive preference and satisfaction with very little education. Some studies report that poor women think that because they are poor they are stupid. These forms of enactment of poverty, just like crime and violence as the forms of survival, are often toxic for the poor. Anger at a certain ascribed gender identity could propel a community, or groups of girls or boys, out of poverty or lack of schooling. It could also, however, take the form of "acting out" dangerous gender identities associated with masculinity and femininity of toughness, rejecting schooling and inflicting harm. I have referred to these processes as entailing "gender as a verb". It may be that girls and boys repeatedly act out and consolidate particular gender identities at school. This may happen because they are trying to use school as a platform to escape from particular identities and relationships, to cross the borders or cut the mesh of "the net", or because they accept that schools are "good enough" because they are poor and hence "deserve" no better. From this standpoint, gender equality in education is about setting the conditions and processes that allow people critically to review processes and to act in relation to their own wellbeing.
The three different approaches to thinking about gender equality and education may each be useful, but when applied in isolation, each is limited. The three approaches to thinking about gender equality in education need to complement each other and there is therefore a need for a fourth framework which is associated with capabilities and empowerment. ${ }^{9}$ Gender inequalities in education are multidimensional. They involve crossing the line of enrolment or attendance. Formal gender equality may well be in place in the public space of the school and visible in figures on enrolment and attainment, observations of teacher engagement with pupils and analysis of learning materials. Much gender inequality, however, is associated with informal school spaces, private relations within families and public inequalities in the labour market or particular institutions. Forms of co-operation and conflict within households, and deeply entrenched codes of behaviour confirmed by legal and economic frameworks often relate to who takes care of small children, the sick, the disabled and the elderly, and how heteronormative social interactions between young people play out. These all shape the forms of opportunity which schooling may guarantee. Formal gender equality in schools may co-exist with widespread media representation of inequality or the tenets of religion or legal frameworks which limit the mobility of women or their capacity to own or inherit property. Overt or covert condoning of violence against women can also undermine or render fragile the achievements of gender equality in education institutions. Gender equality in the public sphere of the school may contribute to shifting some of the gender inequalities of the private sphere or certain public institutions, but its capacity to do this without shifts in other areas of social, cultural, political and economic relations is limited. This becomes an even more intense 
struggle in countries where large proportions of women and girls do not attend or complete school. Thus concern with equality understood in terms of girls and boys crossing a line need to be complemented by a meaning of equality which entails changing the "netlike" relationships of inequality and eradicating the destructive "fuels" associated with particular forms of femininity and masculinity. This multi-dimensional notion of equality may be called "empowerment" for shorthand, but this idea still lacks a coherent institutional form or clear indicators to monitor progress. In synthesising some recent work on empowerment and education, I have tried to draw out the importance of thinking about empowerment in relation to multiple institutional locations and critical professional discussion in order to realise the potential for gender equality in education. Among the many processes entailed would be addressing (i) the problem of labour market segmentation, (ii) political, cultural and social exclusions, (iii) girls' and boys' adaptive preferences, (iv) limited information flows, and (v) the importance of both intellectual and political alliances. ${ }^{10}$

These four different approaches to thinking about gender equality and education can be usefully deployed when looking at the existing international frameworks.

\section{International Frameworks and Gender Equality in Education}

In reflecting on ten years work in taking forward the international framework associated with the Millennium Development Goals (MDGs) - in which concern with gender and education feature, as discussed below - Charles Gore has drawn attention to the Faustian bargain which the framework represents. He argues that it represents a shift from a "procedural conception" of interna- tional society with a "common respect for a set of rules, norms and standard practices", such as those associated with the Universal Declaration of Human Rights (UDHR) ${ }^{11}$ or the Beijing Declaration and Platform for Action $^{12}$, to a "purposive conception", where the stress is on a "co-operative venture to promote common ends". ${ }^{13}$ For Gore, a "procedural conception" entails a maximalist view of development in which aspects of equality and flourishing are goals for rich and poor countries. Conversely, a "purposive conception" is associated with a minimalist view, which ensures that the most deprived cross a threshold of adequate provision. This might mean earning a dollar a day or completing a primary cycle of schooling.

By implication, both the procedural and the purposive approach face a problem relating to the nature of the social contract that underpins them. The more demanding the social justice content of the procedural approach, the more difficult it becomes to secure full human rights or gender equality through agreements at all levels, from multinational conventions, to national governments, down to local assemblies. The more minimal the purposive agreement, the easier it might be for governments to sign up and follow through with action. However, this begs the question of whether governments are able to implement purposive agreements and how these are understood at the sub-national level. This point is often made in relation to the difficulties of realising the MDGs in many countries in Africa, which came to the project in 2000 from a very low base. ${ }^{14} \mathrm{~A}$ separate question is whether the purposive agreements associated with the MDGs represent a wide enough range of ideas of wellbeing and gender equality in education, or whether a more expansive purposive arrangement is necessary and feasible. ${ }^{15}$ 
The next section reviews certain international frameworks on gender equality and education using Gore's distinction between purposive and procedural approaches, and draws on my own differentiation between the four different frameworks for thinking about gender equality and education.

\section{Purposive or Procedural? International Frameworks on Gender Equality and Education}

In terms of Gore's analysis, the minimal purposive framing of the MDGs represented a shift from the more procedural concerns of the previous frameworks which stressed rights and equality. However, the initial specification of rights in the UDHR is quite close to the first notion of gender equality in education I outlined, with a notion of "gender as a noun" and education as a particular level of school provision. Article 26 of the UDHR sets out the universal right to education, irrespective of gender. It also sets out a universal right to free and compulsory schooling only at the "elementary and fundamental stag-

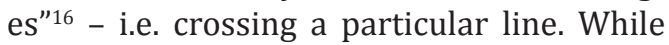
technical and professional education are to "be made generally available" and higher education "shall be equally accessible to all on the basis of merit", ${ }^{17}$ there is no strong or explicit commitment to gender not being used in an exclusionary way at these levels. Further, the concern to protect the prior right of parents "to choose the kind of education that shall be given to their children"18 has subsequently been used to rationalise girls being taken out of school early in order that they might marry or fulfil particular duties associated with forms of identification. ${ }^{19}$ Thus the fuller understandings of gender equality and education set out in the formulations associated with "gender as an adjective" and "gender as a verb" are not fully addressed in this initial procedural formulation.
However, later international law instruments work with wider understandings of gender and education and set out the procedural vision in greater depth. The International Covenant on Economic, Social and Cultural Rights (ICESCR), ${ }^{20}$ which came into force in 1976, affirmed "the equal right of men and women to the enjoyment of all economic, social and cultural rights". ${ }^{21}$ ICESCR explicitly recognises that free and compulsory education should not be confined just to the primary level as it states that secondary education should be made "generally available and accessible to all by every appropriate means, and in particular by the progressive introduction of free education". ${ }^{22}$ Further, it also sets out the prospect of higher education being made widely available at no cost and "on the basis of capacity". ${ }^{23}$ There is a commitment here to the continuous improvement of the material conditions of teachers, ${ }^{24}$ and while the rights of parents to choose schools other than those provided by the state are acknowledged to "ensure the religious and moral education of their children in conformity with their own convictions", ${ }^{25}$ it is specified that neither this nor any other clauses on the provision of education should be implemented so as to undermine the general specifications regarding education set out in Article 13. ${ }^{26}$ Education should be:

"[D]irected to the full development of the human personality and the sense of its dignity, and shall strengthen the respect for human rights and fundamental freedoms (...) that education shall enable all persons to participate effectively in a free society, promote understanding, tolerance and friendship among all nations and all racial, ethnic or religious groups, and further the activities of the United Nations for the maintenance of peace". ${ }^{27}$ 
These clauses attempted to deal with the ambiguity in the UDHR that could be interpreted as sanctioning parents taking adolescent girls out of school because religion required early marriage, or parents choosing, on religious or ethnic grounds, schools that presented a form of indoctrination under the guise of education. ICESCR thus extended considerably the range of education rights and widened the scope of where gender equalities must be seen to interlock. However, it did not deal in any detail with questions of educational content. Thus to some extent it may be seen to be addressing the concerns of the second framework for thinking of "gender as an adjective" and schooling as "a net", enabling or restricting the protection of rights.

Much more detailed attention to addressing these concerns is evident in the Convention on the Elimination of All Forms of Discrimination against Women (CEDAW) ${ }^{28}$ and the Convention on the Rights of the Child (CRC). ${ }^{29}$ CEDAW was adopted by the UN in 1979 and has been ratified and/or acceded to by all but seven member states, albeit often with provisos and reservations regarding certain obligations. CEDAW does not explicitly address the question of how much education women have a right to, but it does give more detail on features of gender equitable education. It stipulates that states "shall take all appropriate measures to eliminate discrimination against women in order to ensure to them equal rights with men in the field of education". ${ }^{30}$ It also calls for equality in a range of different educational sites including (i) adult education, (ii) career and vocational guidance, (iii) access to the same curricula, (iv) examinations and teaching staff, (v) the elimination of gender stereotypes in textbooks, (vi) access to scholarships, (vii) sport, and (viii) the establishment of special programmes for young women who have left school prematurely. ${ }^{31}$ There is also a particular provision which deals with the importance of access to educational information. ${ }^{32}$ Although this is phrased in terms of information with regard to family planning, it has some important implications, as outlined further below.

CRC, ratified by the General Assembly in 1989 , is the fullest statement of the nature of rights in education regardless of gender or any other differences. Some of the most notable provisions protect the rights of children to (i) preserve their own identities, ${ }^{33}$ (ii) participate in discussions and affirm views, ${ }^{34}$ (iii) access through the media to information of "social and cultural benefit",35 (iv) protection from "all forms of physical or mental violence, injury or abuse, neglect or negligent treatment, maltreatment or exploitation, including sexual abuse" ${ }^{36}$ With regard to schooling, CRC affirms that primary and secondary education should be made available and accessible and that measures should be taken to make secondary education free and to support school attendance. ${ }^{37}$ Ignorance and illiteracy are also to be eliminated by "modern teaching methods". ${ }^{38}$ With regard to the content of education, CRC envisages education which develops (i) "the child's personality, talents and mental and physical abilities to their fullest potential" and (ii) respect for human rights and fundamental freedoms, ${ }^{39}$ but it does not address in any detail contesting ideas about gender inequality. Thus, ICESCR, CEDAW and CRC the three UN human rights instruments with the strongest purchase on implementation by member states - while containing full statements on access to education, are much less explicit on the content of that education, the teaching process, and the treatment of children at school, although CRC does have a clear statement on children's protection from violence. Together, the three treaties 
do, however, provide some procedural approaches relating to the second framework for thinking about gender equality in education - "gender as an adjective" and schooling as "a net" of relationships of power.

A further version of the procedural approach has been articulated in a number of declarations associated with women's organisations and these may be read as versions of the "empowerment" approach which I classified as a fourth framework. The Beijing Declaration and Platform for Action, adopted by virtually every UN member state in 1995, gave particular prominence to the education and training of women in Strategic Objective $B^{40}$ and to the concerns of the girl-child in Strategic Objective $12 .{ }^{41}$ Under Strategic Objective 2 , detailed attention is given to gender equality and women's rights with regard to access, progression and completion of different levels of schooling, the quality of education provision, particularly content and organisation, and addressing inequities through monitoring and research, building lifelong learning pathways and enhancing women's participation in leadership and decision-making, access to information, and participation in sport and artistic and cultural arenas. The Beijing Declaration and Platform for Action is the fullest statement of gender equality in education as an international aspiration, but paradoxically, the least implemented.

In 2010 there was an attempt at a conference organised by The UN Girls' Education Initiative (UNGEI) to update and expand upon some of the gender equality and education vision expressed at Beijing. ${ }^{42}$ According to the resulting Dakar Declaration on Accelerating Girls' Education and Gender Equality (the Dakar Declaration), ${ }^{43}$ despite the progress that had been made in enrolments and attainment, "poor quality of education, extreme poverty, structural inequality and violence against girls continue". ${ }^{44}$ The Dakar Declaration spells out a meaning of gender equity as follows:

"Achieving equity in education will entail putting in place a rights-based empowerment framework that will target the most vulnerable and transform power hierarchies in learning spaces, communities and policy structures in order to give poor and vulnerable girls a voice and ensure that their right to quality education is sustained." 45

It then goes on to highlight the need to think about gender in relation to "quality" education in multiple learning environments, to consider the multidimensionality of poverty, and to work on questions of violence against women and girls. The Dakar Declaration concludes:

"We envision a world in which a special initiative for girls' education is no longer needed - a world in which all girls and boys are empowered through quality education to realize their full potential and contribute to transforming their societies, so that gender equality becomes a reality." 46

The Dakar Declaration expresses a full version of the intersecting views of gender, equality and education which I have associated with the empowerment framework, and it is based on a procedural view of global society. Despite being adopted at a UNGEI conference, the Dakar Declaration was subsequently very rarely used by UNGEI. ${ }^{47}$ Its procedural empowerment framing did not mesh comfortably with the stress on purposive approaches to international frameworks that had gained in prominence since 2000 .

In the period after 1995, the focus of work on gender equality and education carried out by multilateral organisations, gatherings 
of governments and the work of NGOs has largely moved away from the expansive vision of the Beijing Declaration and Platform of Action and the more progressive aspects of CRC towards more limited interpretations of gender equality in education drawing on Gore's version of a purposive approach. In 2000, governments, multi-lateral organisations and civil society coalitions signed up to the Dakar Framework for Action, Education for All: Meeting our Collective Commitments $(\mathrm{EFA})^{48}$ and the Millennium Development Goals (MDGs). The EFA has six goals, with one explicitly focussed on gender equality and three concerned with aspects of girls' and women's rights. ${ }^{49}$ The six goals are:

- The expansion and improvement of early childhood education;

- Access to free, compulsory education of good quality for all children;

- All learning to be appropriate for children and life skills to be included in learning;

- Improvement in adult literacy;

- Gender disparities in primary and secondary education to be removed; and

- All aspects of the quality of education to be improved including measurable learning outcomes.

The EFA gives much more detail regarding education systems than had previously been set out in ICESCR, CEDAW, or CRC, and identifies literacy, quality and learning outcomes as important features of education. With regard to gender equality, however, its vision largely addresses "gender disparities", and apart from its concern with women's literacy and early childhood education, it did not set out a vision regarding how gender equality in education might be understood. It can largely be read as working within the framework of "gender as a noun" and equality as parity, although its concern with some sites beyond school nudges it slightly towards the second framework associated with "gender as an adjective". However, the stress on monitoring and evaluating the implementation of EFA through particular indicators concerned with gender parity in annual Global Monitoring Reports published by UNESCO made it very difficult for the EFA to be used in relation to a procedural, rather than a purposive, approach.

An even more purposive approach and minimalist understanding was evinced in the MDGs adopted by virtually every government at the UN General Assembly in 2000. The MDGs were organised so that governments could monitor progress towards particular goals against specified targets, each of which was further delimited by an indicator. MDG2 aims to achieve universal primary education. The target entailed that by 2015 all children will have completed primary school. The indicators comprised: (i) net enrolment ratios in primary school, (ii) the proportion of children who complete a primary cycle, and (iii) the literacy rate of 15-24 year old women and men. MDG3 aims to promote gender equality and empower women. The target is to eliminate gender disparity at all levels of education, and the indicators are (i) the ratio of girls to boys in primary, secondary and tertiary education (gender parity), (ii) the share of women in wage employment in the non-agricultural sector, and (iii) the proportion of seats held by women in national parliaments. ${ }^{50}$ It can be seen that the MDG targets and indicators move away from the more substantive views articulated in ICESCR, CEDAW, CRC, the Beijing Declaration and Platform for Action and the Dakar Framework for Action, about gender equality which aim to promote human rights and redress stereotypes and violence. These approaches have been replaced with a stress on processing girls and boys through school, the attainment of literacy and employment in 
waged work. The MDG framework works explicitly with the notion of "gender as a noun" and schooling and poverty as set by particular kinds of "lines".

This brief review of the international frameworks relating to gender equality in education highlights a number of trends. Firstly, the tighter the form of legal agreement between states (with ICESCR, CEDAW and $\mathrm{CRC}$ representing the most binding instruments), the less detail there is to aspects of education organisation (such as curriculum, teacher training, management, or language policy) that might bear on gender equality. Secondly, the declarations associated with large-scale international convening regarding education - the EFA and the MDGs - give little substantive attention to gender equality, and dilute the idea to no more than gender parity. Thirdly, the more expansive the articulation of a vision of women's rights and gender equality in education in declarations such as those adopted at Beijing in 1995 and in the Dakar Declaration, the more limited the international, national and local bodies to give them institutional form. In order to show how these processes work in particular country settings, the next section reports some findings from the Gender, Education and Global Poverty Reduction Initiatives (GEGPRI) project. I will refer to the deployment of the different approaches to gender equality and education discussed above and show how difficult the implementation of the more procedural frameworks on the ground has been.

\section{Negotiating International Frameworks on Gender Equality and Education in Kenya and South Africa}

The GEGPRI project aimed to examine empirically initiatives engaging with global aspirations to advance gender equality in and through schooling in contexts of poverty. Between 2007 and 2011, ten case studies were conducted. These comprised six government bodies, namely the Department of Education in South Africa, the Ministry of Education in Kenya, a provincial department of education in each country, and a school in each country in a matched neighbourhood on the edge of a large city serving a poor population. In addition, four case studies were made of non-statutory bodies - an NGO working on questions of poverty and schooling in a rural setting in each country, and an NGO working at the national level engaged in discussions with global networks. The case studies were supported by a number of interviews with staff working on aspects of gender and education in selected global organisations. Research methods comprised documentary analysis (including review of websites and publications over ten years), interviews and focus group discussions (133 hours), observations, field notes, and report back meetings in each research site on preliminary findings. The research was conducted over three years to enable some documentation of change. In all of the research settings, engagements with the global frameworks were examined, and the particular meanings attributed to gender, poverty and education were explored.

Comparative case study allowed investigation of similar processes - such as negotiations with global policy agendas on gender, education and poverty reduction - in somewhat different sites, selected as locations of different levels of engagement with the global policy agenda (vertical comparisons) and different state and non-state formations (horizontal comparisons). Kenya and South Africa were selected as the research settings because both countries had put in place policies to address poverty reduction, the expansion of education provision, and 
gender equality, and were active players in relation to the global policy frameworks in these areas. ${ }^{51}$ It is notable, however, that the respective situations of these two countries in relation to global policy-making are very different. South Africa is a member of the UN Security Council and the G20, while Kenya has been the recipient of a substantial aid package and is subject to constant international scrutiny regarding corruption and political violence.

South Africa and Kenya are both highly unequal societies, with high Gini co-efficients and large populations of very poor people living close to people who are comfortably off and many who are very wealthy. Both have active women's movements, although their emphases have been different. In South Africa, gender equity has enjoyed policy attention since 1994 , although the extent to which it is seen as a priority has fluctuated. In early postapartheid policy, discussion of gender equity in education expressed an early promise of non-discrimination and equality of opportunity. This orientation has moved through a phase with a stress on gender-neutrality to the current period where gender is often seen as a moral issue closely associated with sexuality. In Kenya, the movement towards more gender equity in policy came from the "bottom-up", through women's rights groups mobilising on a wide range of issues from political leadership to environmental degradation, and from the "top-down", through global institutions engaging in different ways with ruling elites. A gender and education policy was developed in 2007, and gender equity figures featured prominently in the policy language associated with aid relationships. These similarities and differences between the two countries offered the potential for the research to yield rich insight into how the cases did and did not vary.
Both Kenya and South Africa have signed up to a large number of international instruments on gender equality and education. (see Table 1). Prominent political leaders from both countries played a high level role in supporting EFA, and both sent large delegations to the UNGEI 2010 conference in Dakar.

Despite these commitments on paper, however, the statistics highlight areas of concern regarding the realisation of gender equality in education, particularly for the poorest members of society and even in terms of the limited measures associated with measuring gender parity and enrolment. Two measures of enrolment are frequently used. The net enrolment ratio (NER) measures the proportion of the age group required to be in school which is enrolled. The gross enrolment ratio (GER) measures the total enrolment in a specific level of education, regardless of age, and is expressed as a percentage of the population in the official age group corresponding to the level of education. If there are large numbers of overage or underage children at school, the gross enrolment may be over $100 \%$. The Gender Parity Index (GPI) is the ratio of female to male values in NER or GER. If there are equal numbers of women or men, the GPI is 1.00. A GPI of less than 1 indicates there are more men, and a GPI of more than 1 indicates more women.

The gender parity levels in primary net enrolment were equal in Kenya in the early 1990 s and in both countries in 2007. In the 1990s, slightly more girls than boys were enrolled in primary school in South Africa, and this is also evident in Kenya in 1999. However, the general trend over this period is for parity at primary level. For secondary education, there is only comparative data on the gross enrolment ratio. It can be seen that in Kenya this is much more in favour of boys than girls, while in South Africa the 
Table 1

\begin{tabular}{|l|l|l|}
\hline & Kenya & South Africa \\
\hline ICESCR & 1972 & $\begin{array}{l}\text { Signed in 1994 but not } \\
\text { yet ratified. }\end{array}$ \\
\hline CEDAW & 1984 & 1995 \\
\hline CRC & 1990 & 1995 \\
\hline $\begin{array}{l}\text { World Declaration on } \\
\text { Education for All (1990) }\end{array}$ & 1990 & $\begin{array}{l}\text { Readmitted to UNESCO in } \\
1994 \text { and filed first report }\end{array}$ \\
\hline $\begin{array}{l}\text { Beijing Declaration and } \\
\text { Platform for Action (1995) }\end{array}$ & 1995 & 1995 \\
\hline $\begin{array}{l}\text { Dakar Framework of Action on } \\
\text { Education for All (2000) }\end{array}$ & 2000 & 2000 \\
\hline $\begin{array}{l}\text { Millennium Development Goals } \\
\text { (2000) }\end{array}$ & 2000 & 2000 \\
\hline $\begin{array}{l}\text { Protocol to the African Charter } \\
\text { on Human and Peoples' Rights } \\
\text { on the Rights of Women in } \\
\text { Africa (2003) }\end{array}$ & $\begin{array}{l}\text { Party to } \\
\text { protocol }\end{array}$ & Party to protocol in 2003 \\
\hline \begin{tabular}{l} 
African Union Gender Policy \\
\hline
\end{tabular} & 2009 & 2009 \\
\hline
\end{tabular}

trend is in the opposite direction. Despite relatively good enrolment rates at primary and secondary school in South Africa and at the primary level in Kenya, girls' attainment, particularly for those from the lowest quintiles, is a matter of concern in both countries. Some effects of this can be seen in the adult literacy figures in both countries. Thus although for youth aged 15-24, more young women than men are literate, and young women are a smaller proportion of youth illiterates than young men, in both countries there are high numbers of adult illiterates - nearly 3 million in Kenya and nearly 4 million in South Africa, and in both countries women are a majority (see Table ${ }^{52}$ ).
The many facets of gender inequality in education in each country are apparent in studies of conditions within school concerning discrimination in relation to curriculum, ${ }^{53}$ pedagogy,,$^{54}$ conditions of employment of teachers ${ }^{55}$ and head teachers, ${ }^{56}$ and gender-based violence in and associated with school. ${ }^{57}$ The low educational attainment of the poorest is manifest not only in low test scores and high rates of illiteracy, but also in lack of knowledge regarding how to access health and welfare services. A number of commentators in both countries also draw out how, despite girls' enrolment in school and some high profile women in political leadership, women still earn less than men, struggle to advance gender equality 
Table 2

\begin{tabular}{|l|l|l|}
\hline & Kenya & South Africa \\
\hline GPI primary NER 1991 & 1.00 & 1.03 \\
\hline GPI primary NER 1999 & 1.01 & 1.01 \\
\hline GPI primary NER 2007 & 1.00 & 1.00 \\
\hline GPI secondary GER 1991 & 0.85 & 1.18 \\
\hline GPI secondary GER 1999 & 0.96 & 1.13 \\
\hline GPI secondary GER 2007 & 0.88 & 1.05 \\
\hline Youth (15-24) literacy GPI 2008 & 1.01 & 1.01 \\
\hline $\begin{array}{l}\text { Numbers 000 (\% women) of youth 15- } \\
\text { 24 illiterate }\end{array}$ & $634(46.3)$ & $322(38.9)$ \\
\hline Adult (15 \& over) literacy GPI 2008 & 0.92 & 0.98 \\
\hline $\begin{array}{l}\text { Numbers 000 Adults - 15 \& over - (\% } \\
\text { women) illiterate }\end{array}$ & $2989(64.2)$ & $3790(55.3)$ \\
\hline
\end{tabular}

demands in public and private settings, and have to endure sexist media. ${ }^{58}$

Why, despite the commitment of both governments to many international instruments concerned with gender equality in education has this been so difficult to realise in practice? Looking at the data collected from the interviews and discussion groups conducted by the GEGPRI researchers in different sites, a number of key problems emerge. The first relates to process. Thus, although part of the argument for taking a purposive approach in the MDGs and EFA, was that it was much more achievable, because the process would be simpler and more easily understood than the complex interlocking rights invoked by the procedural approach, in practice the sense of dislocation from the MDG project was just as evident as that often attributed to more procedural human rights frameworks. In many sites of implementation, there was a sense that the international instruments had been adopted in places that were both geographically and socially far away from the sites of implementation. There was a strong sense at the Ministry of Education in Kenya that the MDGs were important, partly because they were linked with a substantial aid package, and a sense in South Africa that the MDGs had done no more than confirm what was already in the Constitution. ${ }^{59}$ The national staff of the global NGO working in a large city in each country shared a sense of ownership in relation to the MDGs and the EFA and their presuppositions with a global community, ${ }^{60}$ potentially as a result of contact through email, visits and access to shared literature. At some distance from the city hubs, however, provincial government 
officials, teachers and local NGO workers knew only vaguely about the international framework, and the issues which it raised. In the place of knowledge and a sense of engagement, there was a feeling of confusion, exclusion and sometimes cynicism. Although the South African provincial officials did feel connected to the MDG process, in Kenya, provincial officers felt that the MDGs had been devised a long way away from their day-today experiences. Some had heard about the MDGs, but did not know what they were. One officer explained:

"I tell you the first time I heard about the MDGs and you will not believe, it was last year when I went for a Ministry of Planning (...) workshop organized at the province here. I went to represent my boss (...) That's the first time I heard about MDGs (...) Really, it's like they belong to other people."61

Similarly the teachers at the two schools saw the MDGs and EFA, to the extent they knew of them, as very "far away" from their own experiences. The MDGs are seen as remote and spoken about in the public media, with little bearing on the things that people experience or have capacity to effect. Examples of some of the responses given are as follows:

"I do hear about it [MDGs and EFA] but I've never given my time to get an explanation about it because it's never touched [me]. I've never get the real explanation about it."62

"[T]here is the Millennium Development Goals but where? And what the Millennium Development Goals say to whom too? You know that [...] they must come down. Don't just say when we have TV and say that there is something, that there's change what - but we don't have that change!"63
For participants in the case studies in the provincial NGOs in both countries, the global policy framework was either something they had heard of very generally or not at all. In South Africa, most of the six village-based facilitators who participated in a focus group discussion in June 2009 had only heard of the global goals by name and did not know what they meant. Village-based NGO officials in South Africa, interviewed also in June 2009, reluctantly recognised that gender equality was a legal right in the national Constitution, and that there were policies governing these rights in schools. But gender was not part of the NGO remit, even though much of their work was with women. A village facilitator in South Africa said: "The NGO never talks about the global goals". ${ }^{64}$ In Kenya, there was a similar sense that the organisation's priorities were not being framed by, or linked to, the global policy framework. One NGO worker said: "There are so many policies around here (...) we don't disseminate those policies". ${ }^{65}$ On the MDGs, the view was one of indifference and distance. One NGO worker noted sceptically that "another issue is whether the people own the global declarations. The issue is not even whether they own the MDG's but rather understand, comprehend and know them." In another exchange with an interviewer, the issue of how the MDGs could be discussed at the grassroots was raised. The view was that the MDGs were too particular, and that the nature of the work which the organisation did was general and integrated with its own programme of education, not the steer from the MDGs:

"Interviewer: How do you make them comprehend these MDG's?

NGO worker: You see when you talk to people it is general. Among the people we have educated, semi-educated, illiterate, semiilliterate and illiterate people." 
It can be seen that the locus of concern with the international frameworks clusters at centres of power in the national department of education or a global NGO, but translating a sense of engagement and concern with global processes in this purposive form and a sense that they might develop and support local work has not been happening.

This links with a second problem which relates to meaning, information and the way in which ideas about rights have been translated by practitioners. A number of papers have drawn out how the emphasis within the MDG and the EFA on results-based management has generated a nexus of attitudes referred to as "blaming the poor". ${ }^{66}$ Thus when teachers or provincial officials are tasked in a hierarchical system with ensuring enrolment or attainment and ensuring that girls are in school, they tend to blame poor parents for not sending children to school, not giving them adequate nutrition to ensure they concentrate and/or not providing sanitary protection. The critique does not go to governments that may not be able to collect sufficient taxes, to an international economic order that does not distribute wealth equally or to employers that make it difficult for parents to combine work and child-care, but rather to the poorest who struggle to enrol their children in school at enormous cost. In South Africa, where the government had provided Child Support Grants to help the poorest families, expressions of "blaming the poor" singled out young girls, who it was alleged got pregnant intentionally to claim the grant. Ideas of "blaming the poor" coincided with another set of ideas on gender referred to as "gender lite", in which officials at all levels of government and the NGOs tended to essentialise girls, thinking about them primarily in terms of vulnerability or sexuality ${ }^{67}$ This attenuated meaning of gender, which often went with a very basic notion of equality associated with parity, blocks a fuller meaning of the nature of gender equality in education and has limited the development of a critically-engaged language of practice in this area.

A third problem relates to measurement, monitoring and research processes. Because the MDGs and EFA have used gender parity as the key instrument for measuring, and because the research community has been slow to come up with instruments that might develop more multi-faceted approaches to reviewing how gender equality is being institutionalised in education settings, the policy language has stayed in a limited zone concerned with parity and has not developed more fully. While an innovative project such as the Right to Education Project (a collaboration between ActionAid, Amnesty International, the Global Campaign for Education and the Open Society Institute) works to promote social mobilisation and legal accountability focussing on legal challenges to the right to education and has developed a wide range of indicators on how rights are being implemented in education in terms of affordability, accessibility, availability and adaptability, ${ }^{68}$ this approach has not been widely adopted by government departments or NGOs and its potential remains largely unrealised.

\section{Conclusion}

The data from the GEGPRI project therefore demonstrates how the purposive approach of the international legal architecture on gender equality in education associated with the MDGs and EFA is being frustrated in its realisation in Kenya and South Africa. This is partly due to a lack of processes to domesticate, popularise and educate key policymakers, government officials, teachers, and school communities regarding its content 
and concerns. It also highlights how the attempt to kick-start work on delivery of the larger rights frameworks through setting more limited and possibly easily attainable targets, such as those associated with the MDGs and EFA, does not necessarily precipitate work on poverty or equality. Indeed, without a vigorous language associated with rights and gender equality in the context of hierarchical government systems, these approaches appear to develop social distance from those whose rights are sorely in need of protection and advancement. Lastly, while the processes of measurement are not themselves the reason it has been difficult to realise rights for gender equality, the very limited indicators which stress parity confirm the notion of "gender as a noun", rather than reveal the nature of the problem of gender inequality in multiple and interlocking sites. This prohibits the development of a political culture that can give substance to the more procedural approaches adopted in some international rights instruments.

None of these processes on their own explain why the international frameworks as- sociated, for example, with the Beijing Declaration and Platform for Action or CEDAW, have been difficult to implement in Kenya and South Africa. They also do not fully explain why there has been a retreat in some international decision-making fora from more detailed substantive engagements with gender equality in education or why the Dakar Declaration was not popularised. However, they do show that even a purposive approach cannot make gender equality in education "just happen". Gender equality in education, in all its multi-faceted forms, cannot be brought into being through the leverage provided by a purposive or a procedural approach confined to top-down strategies. The critical examination of how the relevant international frameworks approach (i) different meanings and aspirations concerning gender equality and education, (ii) the institutional forms to realise these and (iii) the shifts in power and practice that might need to take place, through participatory processes, institutional assessment, and rich flows of information does seem a fruitful place to begin to take the steps towards effective implementation.

1 Elaine Unterhalter is Professor of Education and International Development at the Institute of Education, University of London. The author wishes to thank Libby Clarke for invaluable advice on developing the argument in this article and editorial help in preparing the manuscript for publication.

2 The Gender, Education and Global Poverty Reduction Initiatives (GEGPRI) project was funded by the UK Economic and Social Research Council (ESRC) Award No. RES 167-25-260 under a partnership with the UK Department for International Development (DFID). The project ran from September 2007 to March 2011. The Institute of Education, University of London held the award and co-investigators worked at the University of the Witwatersrand, the University of KwaZulu-Natal, and the Catholic University of Eastern Africa. The full project report, on which this article draws, is Unterhalter, E., Dieltiens, V., Karlsson, J., Onsongo, J., North, A., Makinda, H. and Yates, C., Gender, education and global poverty reduction initiatives. Report on comparative case studies in Kenya, South Africa, and selected global organisations, Institute of Education, 2011. Further examination of some of the themes concerned with the international framework is found in Unterhalter, E. and North, A., "Girls' schooling, gender equity and the global education and development agenda: Conceptual disconnections, political struggles, and the difficulties of practice", Feminist Formations, Vol. 23(3), 2011, pp. 1-22; and Unterhalter, E. and North, A., "Responding to the gender and education Millennium Development Goals in South Africa and Kenya: reflections on education rights, gender equality, capabilities and global justice", Compare, Vol. 41(4), 2011, pp. 495-512. 
3 Unterhalter, E., "Fragmented frameworks: Researching women, gender, education and development", in Aikman, S. and Unterhalter, E. (eds.), Beyond Access: Developing Gender Equality in Education, Oxfam Publishing, 2005, pp. 15-35; Unterhalter, E., Gender, schooling and global social justice, Taylor Francis Routledge, 2007 , pp. 3-19; and Unterhalter, E., "Gender and poverty reduction: The challenge of intersection", Agenda, Vol. 81, 2009, pp. 14-24.

4 UNESCO, Education for All Global Monitoring Report: Reaching the Marginalized, UNESCO Publishing and Oxford University Press, 2010, pp. 138-146.

5 See Unterhalter (2007), above note 3, pp. xii-xiii.

6 See Aikman, S. and Unterhalter, E. (eds.), above note 3; and Skelton, C. , Francis, B. and Smulyan, C. (eds.), International Handbook of Gender and Education, Sage, 2006.

7 See Unterhalter (2007), above note 3, p. 3.

8 See Unterhalter (2009), above note 3, pp. 19-20.

9 See Unterhalter (2007), above note 3, pp. 154-156; and Unterhalter (2009), above note 3, pp. 20-22; see also Morrell, R., Epstein, D., Unterhalter, E., Bhana, D. and Moletsane, R., Towards equality? Gender in South African schools during the HIV and AIDS epidemic, University of Kwazulu Natal Press, 2009, pp. 17-19.

10 Unterhalter, E., "What is equity in education? Reflections from the capability approach", Studies in the Philosophy of Education, Vol. 28(5), 2009, pp. 415-424; see also Unterhalter, E., "How far does this go? Reflections on using the capability approach to evaluate gender, poverty, education and empowerment”, Keynote address at Gender and Education Symposium, CIES Conference, Montreal, May 2011.

11 Universal Declaration of Human Rights, G.A. Res. 217A (III) (1948).

12 United Nations, Beijing Declaration and Platform of Action, adopted at the Fourth World Conference on Women, 27 October 1995.

13 Gore, C., "The MDG Paradigm, Productive Capacities and the Future of Poverty Reduction", IDS Bulletin, Vol. 41, 2010, pp. 70-79.

14 Collier, P., The Bottom Billion, Oxford University Press, 2007; Vandemoortele, J., "The MDG Conundrum: Meeting the Targets Without Missing the Point", Development Policy Review, Vol. 27, 2009, pp. 355-371.

15 Waage, J., Banerji, J., Campbell, O., Chirwa, E., Collender, G., Dieltiens, V., Dorward, A., Godfrey-Faussett, P., Hanvoravongchai, P., Kingdon, G., Little, A., Mills, A., Mulholland, K., Mwinga, A., North, A., Patcharanarumol,W., Poulton, C., Tangcharoensathien, V. and Unterhalter, E., "The Millennium Development Goals: a cross-sectoral analysis and principles for goal setting post 2015", The Lancet, Vol. 376, Issue 9745, 2010, pp. 991-1023.

16 UDHR, Article 26.

17 Ibid.

18 Ibid.

19 See Aikman and Unterhalter, above note 6, pp. 83-89 and 149-152; see also Unterhalter (2007), above note 3, pp. 59-61; Fennell, S. and Arnot, M. (eds.), Gender education and equality in a global context, Routledge, 2008.

20 International Covenant on Economic, Social and Cultural Rights, G.A. Res. 2200A (XXI) (1966).

21 Ibid., Article 3.

22 Ibid., Article 13(2)(b).

23 Ibid., Article 13(2)(c).

24 Ibid., Article 13(2)(e).

25 Ibid., Article 13(3).

26 Ibid., Article 13(4).

27 Ibid., Article 13(1).

28 Convention on the Elimination of All Forms of Discrimination Against Women, G.A. Res. $34 / 180$ (1979).

29 Convention on the Rights of the Child, G.A. Res. 44/25 (1989).

30 See above, note 28 , Article 10.

31 Ibid.

32 Ibid., Article 10(h).

33 See above, note 29, Article 8.

34 Ibid., Article 12. 
Ibid., Article 28(1)

40 See above, note 12, pp. 25-34.

41 Ibid., pp. 109-118.

42 See Unterhalter, E. and North, A., "Girls' schooling, gender equity and the global education and development agenda: Conceptual disconnections, political struggles, and the difficulties of practice", Feminist Formations, Vol. 23(3), 2011, pp. 14-17.

43 UNGEI, Dakar Declaration on Accelerating Girls' Education and Gender Equality, May 2010, available at: http:// www.ungei.org/files/Dakar_Declaration_Eng.pdf.

44 Ibid.

45 Ibid.

46 Ibid.

47 See above, note 42, pp. 14-17.

48 UNESCO, Dakar Framework for Action, Education for All: Meeting our Collective Commitments, 2000, available at: http://www.preventionweb.net/files/7705_DakarFramework.pdf.

49 Ibid., pp. 15-17.

50 UN General Assembly, Roadmap towards the implementation of the United Nations Millennium Declaration: Report of the Secretary-General, UN Doc. No. A/56/326, 2001.

51 Graham, S., "South Africa's UN General Assembly Voting Record from 2003 to 2008: Comparing India, Brazil and South Africa", Politikon, Vol. 38(3), 2011, pp. 409-432; Brown, W., Harman, S. Hurt, S., Lee, D. and Smith, S., "New Directions in International Relations and Africa", The Round Table: Commonwealth Journal of International Affairs, Vol. 98, Issue 402, 2009, pp. 263-267; and Draper, P., Grant, C., Kingombe, C. and te Velde, D., The G20 and African Development, Overseas Development Institute, 2011, available at: http://www.odi.org.uk/resources/ docs/7088.pdf.

52 Sources: see above, note 4, p. 418; and UNESCO and UNESCO Institute of Statistics, Global Education Digest 2010: Comparing education statistics across the world, 2010, pp. 226-227.

53 Chisholm, L. and September, J. (eds.), Gender equity in South African education 1994-2004, HSRC Press, 2005, pp. 1-10 and 55-65; Keet, A. and Carrim, N., "Human rights education and curricular reform in South Africa", Journal of Social Science Education, Vol. 1-2006, 2006; and Chege, F. and Sifuna, D., Girls' and women's education in Kenya: gender perspectives and trends, UNESCO, 2006, p. 36.

54 See Morrell et al, above note 9, pp. 93- 110 and 147-182; Wadesango, N., Rembe, S. and Chabaya, O., "An assessment of the implementation of gender equity policies in schools in South Africa", Anthropologist, Vol. 13(4), 2011, pp. 249-255; and Chege, F., "Researching gender: Explorations into sexuality and HIV/AIDS in African contexts", in Fennell, S. and Arnot, M. (eds.), Gender education and equality in a global context, Routledge, 2008, pp. 102-116.

55 Casale, D. and Posel, D., "Unions and the gender wage gap in South Africa", Journal of African Economies, Vol. 20(1), 2011, pp. 27-59; Omwami, E.M., "Relative change theory: examining the impact of patriarchy, paternalism, and poverty on the education of women in Kenya", Gender and Education, Vol. 23(1), 2011, pp. 15-28; Mugo, J.K., "Investigation into factors hindering women teachers from accessing leadership and management positions in primary schools of Mpeketoni division, Lamu District", Unpublished Master Thesis, Kenyatta University, 2011.

56 Moorosi, P., "South African female principals' career paths: Understanding the gender gap in secondary school management", Educational Management, Administration and Leadership, Vol. 38, 2010, p. 547; Amugune, S.E., "Teachers' attitude towards female school managers in mixed public secondary schools in Nairobi province, Kenya", Unpublished Master Thesis, Kenyatta University, 2011.

57 See Morrell et al, above note 9; Chisholm, L. and September, J. (eds.), above note 53; Moletsane, R., Mitchell, C., Lewin, T., "A critical analysis of gender violence and inequality in and around schools in South Africa in the age of AIDS", Paper prepared for UNGEI conference, Dakar, May 2010, available at: http://www.e4conference.org/wpcontent/uploads/2010/04/10en.pdf ; Saito, M., "Violence in primary schools in southern and eastern Africa - evidence from SACMEQ", Paper prepared for workshop on preventing violence against women, International Institute for Educational Planning, Paris, available at: http://www.unesco.org/new/fileadmin/MULTIMEDIA/HQ/SHS/pdf/ preventing_violence_saito.pdf; Wane, N., "Sexual violence and HIV/AIDS in Kenyan and Ugandan schools: Social Implications for Education Policy Development", Journal of Contemporary Issues in Education, Vol. 4(1), 2009, pp. 71-91. 
58 Tisdell, C. A. and Kiriti, T. W., “Gender Inequality, Poverty and Human Development in Kenya: Main Indicators, Trends and Limitations", Indian Journal of Social and Economic Policy, Vol. 1(2), 2004, pp. 255-281; Wanjala, B. and Were, M., "Gender disparities and economic growth in Kenya", Feminist Economics, Vol. 15(3), 2009, pp. 227-251; Hunter, M., Love in the time of AIDS, Indiana University Press, 2010; Jewkes, R., Dunkle, K., Nduna, M. and Shai,N., "Intimate partner violence, relationship power inequity, and incidence of HIV infection in young women in South Africa: a cohort study", The Lancet, Volume 376, Issue 9734, 2010, pp. 41-48; and Christie, P., "The complexity of human rights in global times: The case of the right to education in South Africa", International Journal of Educational Development, Vol. 30(1), 2010, pp. 3-11.

59 See Unterhalter, E. and North, A., "Responding to the gender and education Millennium Development Goals in South Africa and Kenya: reflections on education rights, gender equality, capabilities and global justice", Compare, Vol. 41(4), 2011, pp. 501-508; Unterhalter, E., "Silences, stereotypes and local selection: Negotiating policy and practice to implement the MDGs and EFA", in Verger, A., Altinyelken, H.K. and Novelli, M. (eds.), Global Education Policy and International Development: New Agendas, Issues and Policies, Continuum, 2012 (forthcoming).

60 See above, note 42, pp. 10-14; and Unterhalter (2012), above note 59.

61 Taken from transcript of interview with Kenya Province Official 2 on 16 September 2008.

62 Taken from transcript of interview with South Africa Principal on 25 March 2008.

63 Taken from transcript of interview with South Africa Teacher 1 on 26 July 2010.

64 Taken from transcript of interview with local NGO staff member 2 on 3 June 2009.

65 Taken from transcript of interview with local NGO staff member 5 on 19 May 2010.

66 Unterhalter, E., Yates, C., Makinda, H. and North, A., "Blaming the poor: Constructions of marginality and poverty in the Kenyan education sector", Compare, 2012.

67 Dieltiens, V., Unterhalter, E., Letsatsi, S., and North, A., “Gender blind, gender-lite : a critique of gender equity approaches in the South African Department of Education”, Perspectives in Education, Vol. 27(4), 2009, pp. 365374; Karlsson, J., "Gender mainstreaming in a South African provincial education department: a transformative shift or technical fix for oppressive gender relations?", Compare, Vol. 40(4), 2010, pp. 497-514.

68 Right to Education Project, Education and the 4 As, 2012, available at: http://www.right-to-education.org/node/226. 